
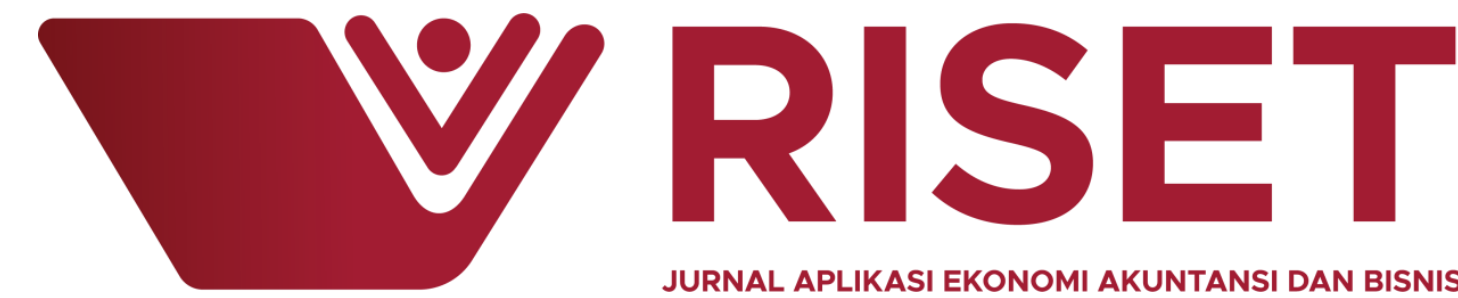

JURNAL APLIKASI EKONOMI AKUNTANSI DAN BISNIS

\title{
FACTORS THAT INFLUENCE ON THE PRICE TO BOOK VALUE OF THE COMPANY IN INDONESIA STOCK EXCHANGE
}

\author{
Henviani ${ }^{1)}$, Riki Sanjaya ${ }^{2)}$ \\ ${ }^{1,2)}$ STIE Trisakti (Trisakti School of Management)
}

\section{INFO ARTICLES}

Factors That Influence On The Price To Book Value Of The Company In Indonesia Stock Exchange

Submitted:

10 - July - 2020

Revised:

30 - August - 2020

Accepted:

25 - September - 2020

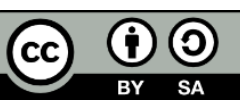

The purpose of this research is to examine institutional ownership, profitability, liquidity, dividend policy, debt policy, firm size, audit committee, managerial ownership in affecting price to book value in nonfinancial companies listed in Indonesia Stock Exchange. This research used 54 listed non-financial companies in Indonesia Stock Exchange, and the data were selected using a purposive sampling method during the research period 2016 until 2018. Data were analyzed using multiple regression methods. The research results show that profitability and debt policy had a significant influence on price to book value. In contrast, for institutional ownership, liquidity, dividend policy, firm size, audit committee, managerial ownership had no considerable influence on price to book value.

Keywords: price to book value, profitability, debt policy, institutional ownership, liquidity, dividend policy, firm size, audit committee, and managerial ownership

E-mail: $\underline{\text { henvianihuang@gmail.com }}^{12}, \underline{R i k i}$ Sanjaya12@yahoo.com $^{2}{ }^{2}$

\section{INTRODUCTION}

The current condition of the Indonesian economy continues to grow, which has created intense competition between companies. The tight game will certainly encourage each company to improve its performance so that the company's goals can be adequately achieved. One of the company's primary goal is to enhance shareholders' welfare through increased company value. One of the proxies that can be used in measuring the company's value is the price to book value. Companies tried to enhance the corporate value of its order to gain confidence and be viewed favorably by investors so that investors' interest in investing in the company is high. Funds obtained from investors can be used by companies to carry out various activities or carry out strategic decisions that can increase company value and its shareholders' welfare. 
The increase in corporate value can also be achieved if the company has the right strategy, as was done by PT Phapros Tbk. Reporting from media Cash on Thursday, February 21, 2019, the secretary of PT Phapros Tbk, Zahmilia Akbar, revealed that throughout the year 2018, PT Phapros Tbk used marketing strategies expansive with its vast new markets, maintain product availability, increase in some line of production and launching some new product. And in 2018, PT Phapros Tbk managed to record positive performance by increasing net profit of $6.41 \%$. Given the importance of corporate value to its survival, it makes this topic interesting to re-examine.

This research is the development of a study conducted by Sukmawardini and Ardiansari (2018). The independent variables used are institutional ownership, profitability, liquidity, dividend policy, and debt policy. Variable-variable is used to examine whether there is an influence of these variables on firm value.

The first difference between this study and the research conducted by Sukmawardini and Ardiansari is the period used. Sukmawardini and Ardiansari used the period 2012 - 2016 as the research year, while in this study, the period 2016 - 2018 was used. The second difference is research previously used manufacturing companies listed in Indonesia Stock Exchange as research data. Investigators earlier utilizing the company's non-financial listed on the Indonesia Stock Exchange data and research objects. The final difference is that this study adds three new variables expected to affect the book value price. This research model is expected to be relatively better at explaining the factors that affect the price to book value, namely company size, audit committee, and managerial ownership. Company size is taken from Yuliana et al. (2018), the audit committee was drawn from research conducted by Yefni et al. (2017). Managerial ownership is taken from a study conducted by Rasyid (2015).

\section{LITERATURE REVIEW}

\section{Agency Theory}

Agency theory explains the relationship between the agent (manager) and principal (investor) that is built so that company goals can be achieved optimally (Jensen and Meckling, 1976). It is not uncommon for company management to have other purposes against the company's goals. This interest can lead to a conflict known as agency conflict.

The existence of different interests, each party will increasingly strive to expand profits for itself. Investors want a return on that as much and as quickly as possible on the made investment. Meanwhile, the agent (manager) fulfilled his interests and accommodated as much as possible. According to his performance to get, for example, a bonus for managers (Sudiyatno and Puspitasari, 2010). In such situations, both the principal and the agent are utility maximizers, and there is no reason for the principal to believe that the agent will always act in the best interest of the principal (Godfrey et al. , 2010). The influence of the conflict between the investor and the manager can make downs of the company's value, this loss, which is called by the agency cost equity by the entity (Jensen and Meckling, 1976).

\section{The value of the company}

Firm value is the price a prospective buyer is willing to pay if the company is sold (Prasetia et al. , 2014). Companies with high value can increase shareholders' prosperity to invest their company (Santoso, 2017).

A high company value will also give a positive signal in investors' eyes to invest in a company. For creditors, the company's value can reflect its performance to pay off its debt so that creditors do not have to worry about providing loans to the entity (Manoppo and Arie, 2016). 


\section{Institutional Ownership and Company Value}

Institutional ownership is the percentage of shares obtained by institutional investors such as insurance companies, investment companies, and banks (Negara, 2019). Institutional investors can play a role in monitoring the agent (manager) of the company. Activities in monitoring activities can change the company's management structure, maximizing shareholder prosperity (Rachmawati and Saputra, 2016).

The proportion of institutional ownership acts as a preventive against waste management that may decline the company (Zahro, 2019). The hypothesis is:

$\mathrm{H}_{\mathrm{a} 1}$ : Owners' institutional influence the value of the company.

\section{Profitability and Company Value}

Profitability is the result of several company management policies and decisions. Profitability in the company is a picture of how well a company generates profit from operational processes implemented to ensure its continuity in the future (Manoppo and Arie, 2016).

Companies with high profitability can make their investors' level of prosperity better to attract other potential investors (Lubis et al. , 2013). Profitability also reflects the effectiveness and success of management as a whole, so that effective company operations will increase the company's profitability and value (Pratama and Wiksuana, 2016). The hypothesis proposed is:

$\mathrm{H}_{\mathrm{a} 2}$ : Profitability influences firm value.

\section{Liquidity and Company Value}

Liquidity is the strength or ability of a company to meet current debt with its current assets. Companies with high liquidity will increase the confidence of outsiders in the company, especially creditors (Sudiani and Darmayanti, 2016). Enhancing its liquidity will give a positive signal to increase investor confidence, thereby increasing its value (Nurhayati, 2013). The hypothesis proposed is:

$\mathrm{H}_{\mathrm{a} 3}$ : Liquidity influences firm value.

\section{Dividend Policy and Company Value}

Dividend policy decides whether the company's profits will be given to shareholders as dividends or profits will be retained in the form of profit to finance investment in the future. The dividend policy is not separated from companies' funding decisions (Sumanti and Mangantar, 2015).

Dividend policy can be a signal to investors about prospects. The dividends distributed to shareholders will make it attractive to shareholders because some investors prefer dividends than capital gains. After all, dividends are more specific (Indriawati, 2018). If the company calls to raise the compensation amount, it will increase the company (Sukmawardini and Ardiansari, 2018). The hypothesis proposed is:

$\mathrm{H}_{\mathrm{a} 4}$ : Policies dividend influence the value of the company.

\section{Debt and Company Value Policy}

Debt policy is a policy that would be used for debt financing. Companies are considered risky if they have a large portion of the debt in the capital structure. However, if a company uses little debt or nothing, the company cannot utilize additional external capital to improve it's operating (Sumanti and Mangantar, 2015). Increasing the use of debt will increase its value, but the excessive debt will reduce the company (Indriawati, 2018). 
Diani (2017) states that the ideal use of debt will increase its income because the return from this fund exceeds the interest paid and increases the owner's equity. The hypothesis proposed is:

$\mathrm{H}_{\mathrm{a} 5}$ : The h debt policy influences firm value.

\section{Company Size and Company Value}

The size of the company is a reflection of the number of assets a company has. Businesses have many assets, the management more flexibility in using existing investments in the company. When viewed from the management's point of view, it will make it easier for them to control the company, increasing company value (Manoppo and Arie, 2016). The hypothesis proposed is:

$\mathrm{H}_{\mathrm{a} 6}$ : The size of the company influences the value of the company.

\section{Audit and Corporate Value Committee}

The audit committee is formed by the board of commissioners to carry out the task of closely supervising the company's management. The existence of an audit committee is essential for company management. The audit committee is a new component in the company's control system. The audit committee is considered a liaison between shareholders and the commissioners' board to handle control issues (Putra et al. , 2018).

The existence of an audit committee is also associated with the principles of transparency governance. Through these principles, the audit committee ensures that the financial statements of a company are not misleading. Thus, investors will provide more value to the company, thereby increasing its value (Yefni et al. , 2017). The hypothesis proposed is:

$\mathrm{H}_{\mathrm{a} 7}$ : Committee Audit influences the value of the company.

\section{Managerial Ownership and Company Value}

Managerial ownership is a proportion of shareholders from management who actively participate in decision-making companies, namely the directors and commissioners. Managerial ownership is one of the corporate governance mechanisms that can reduce agency costs (Ratnasari et al., 2018). Managerial ownership often associated as an effort to increase the value of the company late because the manager than as management as well as the owner of the company will feel the direct result of his decision so the manager would not commit acts which only benefit managers (Suastini et al., 2016). The hypothesis proposed is:

$\mathrm{H}_{\mathrm{a} 8}$ : Owners managerial influence the value of the company.

\section{METHODOLOGY}

\section{Form and Object of Research}

The form of research conducted in this research is causality research. This research's object is non-financial companies listed on the Indonesia Stock Exchange (BEI) for 2016 to 2018. The sample selection technique uses the purposive sampling method, which results in 54 companies. The sample used in this research is 162 company data. (see table 1)

Table 1: Research Sample Selection Procedure

\begin{tabular}{clc}
\hline \multicolumn{1}{c}{ Information } & $\begin{array}{c}\text { Total } \\
\text { Company }\end{array}$ & $\begin{array}{c}\text { Total } \\
\text { Data }\end{array}$ \\
\hline 1. $\begin{array}{l}\text { Non-financial companies listed on the Indonesia } \\
\text { Stock Exchange in the year 201 6 -2 018 }\end{array}$ & 438 & 1314 \\
\end{tabular}


2. Non-financial companies not consistently listed on the Indonesia Stock Exchange during the observation period

3. Non-financial companies whose reporting period did not end on December 31 during the observation period

4. Non-financial companies that present financial statements in currencies other than Rupiah during the observation period

5. Non-financial companies that earn losses during the observation period dividends during the observation period managerial ownership during the observation period

8. Non-financial companies that do not have institutional ownership during the observation period

Number of sample companies

Source: data collected

This study has divided the criteria for non-financial companies listed on the Indonesia Stock Exchange from 2016 to 2018. The non-financial companies that publish financial reports with the financial year ending on December 31 also have financial reports denominated in Rupiah, non-financial companies that consistently earn net income after tax during the observation period, non-financial companies that distribute dividends always, nonfinancial companies that have managerial, and institutional ownership during the observation period.

\section{Variable and Measurement Data}

\section{The value of the company}

The company's value is investors' expectations of the company, which is often associated with its stock price. Firm value is a variable with a ratio scale, and this variable is measured by the following formula (Sukmawardini and Ardiansari, 2018):

$$
\begin{gathered}
\text { Stock Price } \\
\text { PBV }=\frac{\text { Book Value of Shares }}{\text { Shareholder equity }- \text { Preferred equity }} \\
\text { Total Outstanding Common Shares }
\end{gathered}
$$

\section{Institutional Ownership}

Ownership, An institution constitutes a percentage of shares owned by the institution. The measurement scale uses a ratio scale. Institutional ownership can be measured by the following formula (Sukmawardini and Ardiansari, 2018):

\section{Institusional Shares}




\section{Profitability}

$$
\text { INST }=\frac{}{\text { Outstanding Shares }}
$$

Profitability is the ratio $\mathrm{O} n \mathrm{~g}$ can assess a company's ability to generate profits. The measurement scale used in this variable is the ratio scale. Return on assets can be formulated as follows (Sukmawardini and Ardiansari, 2018):

$$
R O A=\frac{\text { Net Income }}{\text { Total Assets }}
$$

\section{Liquidity}

Liquidity is a ratio that measures a company's short-term ability to meet maturing obligations and to meet unexpected cash needs. The measurement scale used in the variable is the ratio scale. Then the current ratio proxies are as below (Sukmawardini and Ardiansari, 2018):

$$
C R=\frac{\text { Current Assets }}{\text { Current Liabilities }}
$$

\section{Dividend Policy}

Dividend policy is a ratio that looks at the share sheet in company income paid to shareholders in the form of dividends (Erfiana and Ardiansari, 2016). The measurement scale used in this variable is the ratio. Therefore, the dividend policy formula is as follows (Sukmawardini and Ardiansari, 2018):

$$
D P R=\frac{\text { Dividends per Share }}{\text { Earnings per Share }}
$$

\section{Debt policy}

Debt policy is a ratio that measures the level of use of debt to the total shareholder equity owned by the company. The measurement scale used in this variable is the ratio scale. The debt policy formula is as follows (Mahdaleta et al. , 2016):

\section{Total Liabilities}

$$
D E R=\frac{\text { Equity }}{\text { Dquities }}
$$

\section{Company Size}

The company's size is a proxy for information asymmetry between the company and the market, which raises a signal that the bigger the company, the more complex the organization (Hantono, 2016). The measurement scale used variable is the ratio scale. Company size is measured using the natural logarithm of total assets with the following proxies (Yuliana et al ., 2018):

$$
\text { Company Size }=\text { Ln Total Assets }
$$

\section{Audit Committee}

The audit committee is an essential factor in ensuring management accountability to shareholders. The audit committee is determined by counting the number of audit committee members owned by the company. The number of audit committees can be seen from its 
annual financial statements (Yefni et al ., 2017). The measurement scale used in this variable is a ratio scale.

\section{Managerial ownership}

Managerial ownership is the proportion of share ownership by directors, management, the commissioner, or any party who actively participates in the company's decision-making. The measurement scale used by this variable is the ratio. Managerial ownership in this study is measured by comparing managerial share ownership with total shares outstanding, with the following formula (Rasyid, 2015):

\section{Managerial Share Ownership}

$$
K M=\frac{\text { Total of Circulated Shares }}{\text { The }}
$$

\section{RESULT AND DISCUSSION}

The results of multiple regression tests can be seen in table 2 below:

Table 2: Multiple Regression Test Results

\begin{tabular}{lll}
\hline & \multicolumn{2}{l}{ Unstandardized Coefficients } \\
Variabel & B & Sig. \\
\hline (Konstanta) & 1.290 & 0.652 \\
INST & -0.715 & 0.432 \\
ROA & 35.670 & 0.000 \\
CR & -0.024 & 0.752 \\
DPR & -0.289 & 0.599 \\
DER & 0.976 & 0.000 \\
SIZE & -0.100 & 0.263 \\
KA & 0.245 & 0.394 \\
KM & 1.512 & 0.933 \\
\hline
\end{tabular}

a Dependent Variable: NP

Institutional ownership has a coefficient value of -0.715 and a significant value of 0.432 , which is greater than alpha 0.05 . So it can be concluded that $\mathrm{H}_{\mathrm{a} 1}$ is not accepted. It means that institutional ownership does not affect firm value. It is because institutional ownership cannot effectively supervise management due to the asymmetry of information. It is challenging to control management behavior, impacting company value (Sukmawardini and Ardiansari, 2018). The results of this study are consistent with research conducted by Sukmawardini and Ardiansari (2018), Adelina et al. (2014), Negara (2019), Raharja (2014), and Harsono (2018).

Profitability has a coefficient value of 35.670 and a significant value of 0.000 , smaller than alpha 0.05 . It can be concluded that $\mathrm{H}_{\mathrm{a} 2}$ is accepted. It means that profitability shows a positive influence on firm value. Nurhayati (2013) found that high income indicates the company's prospects are good, which is considered a trigger for investors to increase demand for the company's stock. The results of this study are consistent with research conducted by Ayu and Suarjaya (2017), Rachmawati and Saputra (2016), Rudangga, and Sudiarta (2016), and Sumanti and Mangantar (2015).

Liquidity has a coefficient value of -0.024 and a significant value of 0.752 , which is greater than alpha 0.05 . It can be concluded that $\mathrm{H}_{\mathrm{a}}$ is not accepted. It means that liquidity does not affect firm value. Sukmawardini and Ardiansari (2018) state that this can happen because liquidity only shows its ability to meet current debt with its existing assets so that investors do not consider liquidity in long-term investment decisions. The results of this study 
are consistent with research conducted by Sukmawardini and Ardiansari (2018), Adelina et al. (2014), Sudiani and Darmayanti (2016), Marceline and Harsono (2017), and Lusiana and Agustina (2017).

The dividend policy has a coefficient value of -0.289 and a significant value of 0.599 , which is greater than alpha 0.05 . It can be concluded that $\mathrm{H}_{\mathrm{a} 4}$ is not accepted. It means that the dividend policy does not affect firm value. Mardiyati et al. (2012) state that the company can generate profits on the company's assets or investment policy. The increasing amount of the company does not always follow the value of dividends. The results of this study are consistent with research conducted by Sukmawardini and Ardiansari (2018), Mardiyati et al. (2012), Nurhaiyani (2018), and Hidayat (2018).

The debt policy has a coefficient value of 0.976 and a significant value of 0.000 , smaller than alpha 0.05. It can be concluded that $\mathrm{H}_{\mathrm{a} 5}$ is accepted. It shows that debt policy has a positive influence on company value. The increasing use of a company's debt will increase its worth because debt can save taxes (Febrianti, 2012). The results of this study are consistent with research conducted by Faisal and Nissa (2018), Manoppo and Arie (2016), Savitri (2017), Pantow et al. (2015), and Febrianti (2012).

Size P company has a coefficient value of -0.100 , and significant value of 0.263 is more generous than alpha of 0.05 . It can be concluded that $\mathrm{H}_{\text {a } 6 \text { is }}$ not accepted. It means that company size does not influence firm value. Manoppo and Arie (2016) state that a large company does not mean guaranteeing this company has a high value. Large companies may not be bold in making new investments before the liability-liability $\mathrm{n}$ was already paid off. The results of this study are consistent with research conducted by Manoppo and Arie (2016), Pantow et al. (2015), Pristianingrum (2017), and Ponziani and Azizah (2017).

The audit committee has a coefficient value of 0.245 and a significant $\mathrm{s}$ e value of 0.394 , which is greater than alpha 0.05 . It concluded that $\mathrm{H}_{\mathrm{a}}$ is not accepted. It means that the audit committee does not influence firm value. It can be caused by the less than optimal performance of an audit committee in carrying out the supervisory and control functions in company management. The formation of an audit committee of a company is sometimes a formality (Raharja, 2014). This study's results are consistent with research conducted by Yefni et al. (2017), Ratnasari et al. (2018), Raharja (2014), and Sukmadijaya and Cahyadi (2017).

Managerial ownership has a coefficient value of 1.512 and a significant value of 0.933, which is greater than alpha 0.05 . So it can be concluded that $\mathrm{H}_{\mathrm{a} 8}$ is not accepted. It means that managerial ownership does not affect firm value. Ratnasari et al. (2018) stated that this was caused by management performance that was not optimal. Due to differences in interests between management and investors. It follows agency theory, which explains that the government has other goals contrary to its main objectives. The results of this study are consistent with research conducted by Rasyid (2015), Ratnasari et al. (2018), Negara (2019), and Sumanti and Mangantar (2015).

\section{CONCLUSIONS}

This research was conducted to obtain empirical evidence regarding the effect of institutional ownership, profitability, liquidity, dividend policy, debt policy, company size, audit committee, managerial ownership on firm value. It concluded that this study's results indicate that profitability and debt policy significantly affect firm value. Institutional ownership, liquidity, dividend policy, size of the company, committee audit, and ownership managerial did not significantly affect its value.

This study has implications for companies to pay attention and keep several factors, such as companies' profitability and debt policies that affect its value. Investors account for 
profitability and debt policies. The issuers should invest in listed companies. Also, to achieve the investment's purpose is one of the capital gains through increasing company value. For regulators to supervise better when determining unusual market activities, one is the change in company value.

The research has some limitations, namely period research used in testing only three years from the period 2016 -2018. Variable data of the sample used in this study still is not normal after been tested utilizing an outlier test. The independent variables liquidity does not meet the heteroscedasticity test; many variables in this study are not proven to contribute to firm value.

Based on the existing limitations, the researcher wants to provide recommendations that might help further researchers carry out research related to firm value. Namely, extending the research period so that the observations' results can be more generalized and can describe the company's actual condition and overcome the problem of normality. Also, fulfilling all the classical assumptions in this study is the heteroscedasticity test, which can be done by adding the amount of research data. For example, adding independent variables may significantly affect firm value, the return of equity, sales turnover, company growth, and other financial ratios.

\section{REFERENCES}

Adelina, S ., Agusti, R ., \& Basri , Y . M . (2014). Oversight spirit Liquidity Ratio, Leverage d late Prof. disability to Company Value pa da Industry Consumer Goods Listed in Stock Exchange Indonesia Year 2010-2012. Jom FEKON, 1, 2 (October), 1-15.

Ayu, D. P . , \& Suarjaya, AA Gede. (2017) . The Effect of Profitability on Company Value with Corporate Social Responsibility as a Mediation Variable in Mining Companies. E-journal of Management of Udayana University, 6, 2, 1112-1138.

Diani, A . F. (2017). The Effect of Dividend Policy, Debt Policy, and Profitability on Firm Value (Case Study of Consumer Goods Companies Listed on the Indonesia Stock Exchange for the Period of 2012-2015). Management research e-journal of the management study program, 1-13.

Erfiana, D. \& Ardiansari A . (2016). The Influence of Agency Problems, Dividend Policy, and Growth Opportunity Moderation Variables on Firm Value. Management Analysis Journal, 5, 244-256.

Faisal, A ., And Nissa, I . K. (2018). The Determinants of Corporate Value in The Indonesia Sharia Stock Index (ISSI). International Journal of Islamic Business and Economics, 2 (December), 75-87.

Febrianti, M. (2012). Factors Affecting Firm Value in the Mining Industry on the Indonesia Stock Exchange. Journal of Business and Accounting, 14, 2 (August), 141-156.

Godfrey, J., Hodgson, A ., Tarca, A . , Hamilton, J . , \& Holmes, S. (2010). Accounting Theory. $7^{\text {th }}$ Edition. Milton: Wiley.

Hantono. (2016) . The Influence of Company Size, Total Debt, Current Ratio, on Financial Performance, and Stock Prices as Moderating Variables. Journal of Micro-Civil Economics Entrepreneurs, 6, 1 (0041pril), 35-44.

Harsono, A. (2018). Factors Affecting the Value of Non-Financial Companies Listed on the Indonesia Stock Exchange. Journal of Business and Accounting, 20, 2 (December), 117-126.

Hidayat, M. (2018). Factors Affecting Price To Book Value. Journal of Business and Accounting, 20, 2 (December), 101-106. 
Indriawati, F. (2018). The Impact of Profitability, Debt Policy, Earning Per Share, and Dividend Policy On The Firm Value (Empirical Study of Companies Listed In Jakarta Islamic Index 2013-2015). Information and Knowledge Management, 8, 4, 77-82.

Jensen, M. C., \& Meckling, W . H. (1976). Theory of the Firm: Managerial Behavior, Agency Costs, and Ownership Structure. Journal of Financial Economics, 3, 4 (October), 305-360.

Kartika, Herlina. 21 February 2019. Booked a Positive Performance in 2018; see the Phapros (PEHA) strategy this year. Kontan, (https://invest.kontan.co.id/news/bukukan-kinerjapositif- on-2018- list the current-year-phapros-peha-strategy, 18 February 2019 ).

Lubis, A . N., Sadalia, I . , Fachrudin, K. A . , \& Meliza, J. (2013). Financial Investor Behavior. Medan: USU Press.

Lusiana, D., \& Agustina, D. (2017). Factors Affecting Firm Value in Non-Financial Companies. Journal of Business and Accounting, 19, 1 (June), 81-91.

Mahdaleta, E . , Young, I ., And Nasir, G . M. (2016). Effects of Capital Structure and Profitability on Corporate Value with Company Size as Moderating Variable of Manufacturing Companies Listed on Indonesia Stock Exchange. Academic Journal of Economic Studies, 2, 3 (September), 30-43.

Manoppo, H ., \& Arie, F . V. (2016). The Effect of Capital Structure, Company Size, and Profitability on the Value of Automotive Companies Listed on the Indonesia Stock Exchange for the 2011-2014 Period. EMBA Journal, 4, 2 (June), 485-497.

Mardiyati, U ., Ahmad, G . N., \& Putri, R. (2012). The Effect of Dividend Policy, Debt Policy, and Profitability on the Value of Manufacturing Companies Listed on the Indonesia Stock Exchange (BEI) for the 2005-2010 Period. Indonesian Journal of Management Science Research, 3, 1, 1-17.

Marceline, L., \& Harsono, A. (2017). The Influence of Good Corporate Governance, Company Characteristics, Liquidity, Leverage, Dividend Policy, and Company Value. Journal of Business and Accounting, 19, 1a (November), 226-236.

State, I . K. (2019). Analysis of the Influence of Good Corporate Governance on Firm Value with Corporate Social Responsibility as a Moderating Variable (Study on the SriKehati Index Listed on the IDX). Journal of Master of Management Unram, 8, 1 (March), 46-61.

Nurhaiyani. (2018) . The Influence of Corporate Governance, Leverage, and Other Factors on Non-Financial Firm Value Journal of Business and Accounting, 20, 2 (December), 107-116.

Nurhayati, M. (2013). Profitability, Liquidity, and Company Size Impact on Dividend Policy and Company Value in the Non-Service Sector. Journal of Finance and Business, 5, 2 (July), 144-153.

Pantow, M. S. R., Pure, S . , \& Trang, I. (2015). Analysis of Sales Growth, Company Size, Return on Assets, and Capital Structure Against Company Value Listed on the LQ 45 Index. Journal of EMBA, 3, 1 (March), 961-971.

Ponziani, R . M., \& Azizah, R. (2017). Firm Value in Non-financial Companies Listed on the IDX. Journal of Business and Accounting, 19, 1a (November), 200-211.

Prasetia, T. E ., Tommy, P ., \& Saerang, I . S. (2014). Capital Structure, Company Size, and Company Risk Against Value of Automotive Companies Listed on the IDX. EMBA Journal, 2, 2 (June), 879-889.

Primary, I, G. B. A., \& Wiksuana, IG. B. (2016) . The Effect of Company Size and Leverage on Firm Value with Profitability as a Mediation Variable. E-Journal of Management of Udayana University, 5, 2, 1338-1367. 
Pristianingrum, N. (2017). The Effect of Size, Profitability, and CSR Disclosure on the Value of Manufacturing Companies Listed on the Indonesia Stock Exchange. SNAPEREBIS, 27-28 (October), 353-364.

Son, D. A . , Kristanti, F . T . , \& Aminah, W. (2018). The Influence of Managerial Ownership, Audit Committee, and Independent Board of Commissioners on Profit Management (Study on Pharmaceutical Sub-Sector Companies on the Indonesia Stock Exchange (BEI) 2013-2016). E-Proceeding of Management, 5, 2 (August), 21932203.

Rachmawati, E . N., \& Saputra, R. (2016). The Influence of Institutional Ownership and Profitability to The Value of Property Company and Real Estate in Indonesia Stock Exchange. Journal of Management Science, 6, 1 (December), 24-36.

Prog, R . S. P . (2014). Analysis of the Influence of Corporate Governance on Company Value. Diponegoro Journal of Accounting, 3, 3, 1-13.

Rasyid, A. (2015). Effects of Ownership Structure, Capital Structure, Profitability, and Company's Growth Towards Firm Value. International Journal of Business and Management Invention, 4, 4 (April), 25-31.

Ratnasari, D . , Chomsatu, Y . , \& Wijayanti, A. (2018). Effect Of Financial Performance And Good Corporate Governance On Value Of Company. EBa Journal, 4, 1 (February), 10-21.

Rudangga, IG . N . G ., \& Sudiarta , G . M. (2016) . The Effect of Company Size, Leverage, and Profitability on Firm Value. E-Journal of Management of Udayana University, 5, 7, 4394-4422.

Santoso, A. (2017). The Effect of Good Corporate Governance on Company Value with Financial Performance as an Intervening Variable. Proceedings of the National Seminar and Call For Economics and Business, 27-28 October, 67-77.

Savitri, D. A . M. (2017). The Effect of Financial Performance on Firm Value with Corporate Social Responsibility as a Moderating Variable. Journal of Management Science and Applied Accounting, 8, 1 (May), 29-45.

Suastini, N. M ., Purbawangsa, I. Breakfast. A . , \& Rahyuda, H. (2016). The Effect of Managerial Ownership and Company Growth on Firm Value in Manufacturing Companies on the Indonesia Stock Exchange (Capital Structure as Moderation Variable). E-Journal of Economics and Business, Udayana University, 143-172.

Sudiani, N. K. A ., \& Darmayanti, N. P . A. (2016). The Effect of Profitability, Liquidity, Growth, and the Investment Opportunity Set on Firm Value. E-Journal of Management of Udayana University, 5, 7, 4545-4574.

Sudiyatno, B., \& Puspitasari, E. (2010). The Effect of Company Policy on Firm Value with Company Performance as an Intervening Variable. Finance and Banking Dynamics, 2, 1 (May), 1-22.

Sukmadijaya, P ., \& Cahyadi, I. J. (2017) . Factors Affecting the Value of Manufacturing Firms. Journal of Business and Accounting, 19, 1a (November), 32-41.

Sukmawardini, D., \& Ardiansari, A. (2018). The Influence of Institutional Ownership, Profitability, Liquidity, Dividend Policy, Debt Policy on Firm Value. Management Analysis Journal, 7, 2, 211-222.

Sumanti, J . C., \& Mangantar, M. (2015). Analysis of Managerial Ownership, Debt Policy, and Profitability on Dividend Policy and Company Value in Manufacturing Companies Listed on the IDX. EMBA Journal, 3, 1 (March), 1141-1151.

Yefni, Zarefar, A . , \& Zarefar, A. (2017). The Effects of Good Corporate Governance for Corporate Value in Plantation Companies at Indonesian Stock Exchange (IDX). Global Academy of Training \& Research Enterprise, 5, 2, 64-69. 
Henviani ${ }^{1)}$, Riki Sanjaya ${ }^{2}$, price to book value, profitability, debt policy, institutional ownership, liquidity, dividend policy, firm size, audit committee, and managerial ownership. . .

Yuliana, I ., Setyaningsih, N. D . , Prajawati, M, \& Muis, A. (2018). Value of The Firm: Company Size, Profitability, and Dividend Share Impact in LQ 45. A Refereed Blind Peer Review Bi-annual Journal, 5, 2 (December), 90-97.

Zahro, H. (2019). Effect of Institutional Ownership and Corporate Value Performance Against Keua n gan as an intervening variable. Journal of Accounting UNESA, 6, 3, 120. 